\title{
Materialidades e maternidades: Agência distribuída e produção de copresença em redes espaço-temporais de cuidado mobilizadas por estrangeiras na Penitenciária Feminina da Capital (PFC) - SP
}

\author{
Bruna Louzada Bumachar* \\ Pedro Peixoto Ferreira**
}

\section{Resumo}

Como tornar presente o ausente? Como se fazer presente onde não se está? Fundamentados em uma pesquisa de campo junto a mulheres estrangeiras presas na Penitenciária Feminina da Capital (PFC, São Paulo), propomos uma maneira de abordar os processos por meio dos quais copresenças espaciais e temporais mediadas são produzidas, mantidas e transformadas a partir do imperativo relacional da maternidade. Constatamos que a criação, a manutenção e a transformação de vínculos e relações entre pessoas que não estão imediatamente copresentes estão diretamente ligadas ao esforço que essas mesmas pessoas investem na mediação desses vínculos e relações, agindo indiretamente na vida uns dos outros. Nesse contexto, falar de "maternidade" é falar da produção, pela mobilização de materialidades diversas (agentes humanos e não humanos), de uma copresença dificultada (mas nem por isso impedida) entre mães e fílhos(as); uma presença corporal defasada, estendida, mediada, que pode ser sentida onde o corpo biológico não necessariamente está.

\section{Palavras-chave}

Prisão. Maternidade. Mediação.

\section{Abstract}

How can one make present that which is absent? How can one be present where one is not? Based on a field research with female foreigners in the Penitenciária Feminina da Capital (PFC, São Paulo), we propose a way to approach the processes by which spatial and

\footnotetext{
* Bruna Louzada Bumachar é doutora em Antropologia Social pela Universidade Estadual de Campinas (Unicamp); e assessora de projetos e pesquisa do Instituto Terra Trabalho e Cidadania (ITTC). E-mail: brunabumachar@yahoo.com.br.

** Pedro Peixoto Ferreira é doutor em Ciências Sociais pela Universidade Estadual de Campinas (Unicamp); professor MS-3 do Departamento de Sociologia (DS) e do Programa de Pós-graduação em Sociologia (PPGS) da Unicamp; e coordenador do Laboratório de Sociologia dos Processos de Associação (LaSPA) na mesma instituição. E-mail: ppf@unicamp.br.
} 
temporal mediated copresences are produced, maintained, and transformed when faced with the relational imperative of motherhood. We verified that the creation, maintainance and transformation of relations between people not immediatelly copresent is directly linked to the effort these same people invest in the mediation of these relations, acting indirectly in each other's lives. In this context, to speak of "motherhood" is to speak of the production, by the mobilization of diverse materialities (human and non-human agents), of a hindered (but not impeded) copresence between mothers and sons/daughters; a corporeal and dephased presence, extended, mediated, that can be felt where the biological body not necessarily is.

\section{Keywords}

Prision. Motherhood. Mediation.

\section{Introdução}

"Zelda played and lost. Arriving back home she now has a second chance with no criminal record in South Africa."

Enquanto a narradora pronuncia essas frases, nos instantes finais de uma matéria em um popular programa jornalístico da televisão sul-africana, a câmera mostra Zelda cruzar o portão de desembarque com um largo sorriso no rosto, em busca das pessoas que a recepcionariam no aeroporto. Sua filha, a primeira a aparecer no enquadramento, corre em direção à mãe e joga seu corpo contra o de Zelda, que logo se agacha para pegar a filha no colo e lhe dar um abraço apertado. Para além da emoção da cena, chama atenção a intimidade e a familiaridade da recepção de Zelda por sua filha, que, agora com cinco anos de idade, tinha apenas três quando a mãe foi presa em São Paulo. Durante seu aprisionamento, Zelda enfrentou diversas restrições normativas para a manutenção do contato e do vínculo com sua filha. Como, então, o vínculo foi mantido entre elas após esse tempo de prisão em um país exterior? Ou, de modo mais amplo: como mães estrangeiras e filhos se relacionam, se é que o fazem, quando separados por dois, quatro, cinco anos ou mais pelo aprisionamento em São Paulo? Como elas constituem tais relações?

Os vínculos familiares têm sido considerados centrais, não apenas na manutenção da vida de quem está dentro ou fora das unidades, mas 
também no próprio funcionamento do sistema prisional. São esses vínculos que indicam uma possibilidade de deixar a "vida do crime", sinalizam uma possível "reinserção à sociedade" (LIMA, 2013; CHRISTIAN, 2005), ou mesmo garantem mais facilmente progressões de regime (CUNHA, 1994). É também por meio desses vínculos que presas acompanham e participam do desdobramento de seus processos judiciais; garantem sua nutrição material e afetiva por meio de "bens de consumo" (GODOI, 2015) e outras "substâncias" (PADOVANI, 2015); recriam um território existencial; suportam o isolamento; participam, de alguma maneira, da vida que corre do lado de fora (BARBOSA, 2005). Mais especificamente para o tipo de material aqui trabalhado, é por meio desses vínculos que presas exercem a maternidade, (re)criam arranjos familiares (GRANJA, 2015), mantêm a guarda dos filhos, os laços afetivos com eles e através deles, ao mesmo tempo que se distanciam discursivamente da chave da marginalização imposta pela prisão (LAGO, 2014).

Esses vínculos são, como em qualquer outro contexto, dinâmicos e passíveis de mudanças ao longo do tempo (LEVERENTZ, 2006). Podem minguar diante dos impedimentos institucionais, das distâncias a percorrer e da indisponibilidade de recursos familiares (CHRISTIAN, 2005; HAUGEBROOK et al., 2011; KANE-WILLIS, 2008; MUNRO, 2007); podem também enfraquecer com o aprisionamento de uma parcela das pessoas que compõem a rede de apoio (CUNHA, 2002; GOMES; GRANJA, 2015) ou com o "abandono" (ausência) de uma das partes. Esse abandono é retratado mais fortemente em unidades femininas (LEMGRUBER, 1983; MOKI, 2005; PAZ, 2009; LAGO, 2014; NEGRETTI, 2015), podendo ter como foco a relação conjugal com maridos e parceiros (FARRELL, 1997; DODGE; POGREBIN, 2001; PRADO, 2003) e/ ou com os filhos (GURSANSKY et al. apud KARVELI et al., 2012). Quando o vínculo é assim comprometido, presas(os) tendem a sofrer ansiedade, tristeza e medo (GRIMBERG, 2009; KARVELI et al., 2012), com uma maior precarização da vida (material, afetiva e processual) dentro da prisão, com desconfianças advindas de outras(os) presas(os) e maus-tratos por parte de funcionários (LIMA, 2013), ou com avaliações negativas feitas pela unidade prisional, o que pode gerar atraso de benefícios/progressão de regimes (CHRISTIAN, 2005). Nota-se que os obstáculos à manutenção dos laços familiares são um fator determinante das dificuldades enfrentadas na experiência de encarceramento e, mais ainda, na de encarceramento em um país exterior. 
No caso da Penitenciária Feminina da Capital (PFC, São Paulo) ${ }^{1}$ não é diferente. As estrangeiras presas na PFC, das quais 76\% declaram ser mães, enfrentam diversas restrições para a manutenção do vínculo e da relação com filhos e demais familiares: cumprem pena em regime fechado sem receber visitas de familiares; não têm o direito de realizar nenhuma ligação telefônica, sequer a cobrar, ao longo de toda a pena; e podem - ou melhor, puderam até 2012 - receber apenas dois telefonemas por ano, cada qual com duração máxima de 20 minutos. Além disso, não têm acesso à internet e só podem se comunicar via correspondências, que demoram semanas ou até meses para chegar ao seu destino final. Diante dessa descontinuidade espaço-temporal criada na relação com familiares e amigos pelas restrições à comunicação durante o aprisionamento, não é de se estranhar que a experiência prisional das estrangeiras tenda a ser vista pelos atores intramuros como um "parêntese" (CUNHA, 1994) no percurso de suas vidas.

Fundamentados em uma pesquisa de campo junto a mulheres estrangeiras presas na $\mathrm{PFC}^{2}$, desenvolveremos aqui, porém, uma perspectiva alternativa a essa, voltada para o emaranhado de relações sociais que vimos se constituírem através, e em torno, da relação de maternidade. Isso pois, mesmo diante do notório isolamento familiar vivido pelas estrangeiras presas no país (SOARES; ILGENFRITZ, 2002; RIBAS; ALMEIDA;

\footnotetext{
${ }^{1}$ A PFC é localizada na cidade de São Paulo. Tinha cerca de 800 presas na época desta pesquisa (2008 a 2012), sendo quase metade estrangeiras. Lá se encontravam mulheres de mais de 60 nacionalidades, com perfis variados, falantes de mais de 30 línguas, mas que traziam em comum, em 95\% dos casos, a causa do encarceramento: o tráfico de drogas, na função de mulas. A massiva maioria se dizia primária no sistema carcerário, residia anteriormente em seus países de origem e não falava português, único idioma dominado pela quase totalidade de presas brasileiras e funcionários. Quase nenhuma chegava com qualquer noção das linguagens criminal e legal brasileiras, ou contava com visitas de parentes e amigos, o que dificultava a consolidação de redes de apoio material e afetivo na capital paulista durante o cumprimento de pena. Por fim, todas estavam submetidas a leis, órgãos e procedimentos jurídicos, não raro, distintos dos das brasileiras, dependiam minimamente da assistência de embaixadas e consulados (que nem sempre se faziam presentes) e contavam com a exclusividade dos serviços prestados pelo Instituto Terra Trabalho e Cidadania (ITTC), ONG que, dentre outras atividades, participa da mediação da relação de estrangeiras com seus familiares..

${ }^{2}$ Este texto é uma versão, muito reduzida e parcial, e com novas experimentações teóricoetnográficas, do capítulo 4 da tese de Bruna Louzada Bumachar. Os dados etnográficos foram obtidos a partir do trabalho de campo multissituado (intra, entre e extramuros), realizado, em grande medida, por meio do trabalho voluntário junto a organizações civis de direitos humanos, dentre as quais o ITTC.
} 
BODELÓN, 2005; ANGARITA, 2008; MATOS; BARBOSA, 2015), consideramos importante observar também a maneira como mulheres mobilizam artefatos, objetos técnicos e outras pessoas na manutenção, por meio de redes espaço-temporais de cuidado, das suas relações familiares.

Nesse contexto, falar de "maternidade" é falar da produção, pela mobilização de materialidades diversas (agentes humanos e não humanos), de uma copresença dificultada (mas nem por isso impedida) entre mães e fílhos(as); uma presença corporal defasada, estendida, mediada, que pode ser sentida onde o corpo biológico não necessariamente está. Abordaremos aqui alguns processos por meio dos quais "copresenças mediadas" (cf. CAMPOS-CASTILHO; HITLIN, 2013) são produzidas, mantidas e transformadas a partir de imperativos relacionais - no caso, a maternidade. Argumentamos que a criação, a manutenção e a transformação de vínculos e relações entre pessoas que não estão imediatamente copresentes estão diretamente ligadas ao esforço que essas mesmas pessoas investem na mediação desses vínculos e relações, agindo indiretamente na vida uns dos outros. Um esforço para promover a circulação de "substâncias compartilhadas" (CARSTEN, 2004) pela mediação material-indiciária do toque, do cheiro, do olhar, do gozo, da degustação, da fala e da escuta, evidenciando não apenas a importância da dimensão presencial no hiato imposto pelo aprisionamento num país exterior, como a possibilidade concreta de mediá-lo.

\section{Fotografias: Rastros de presença}

O álbum da colombiana Sandra está preenchido com dezenas de fotos: imagens da mãe, do pai e o novo namorado da mãe; da irmã, do cunhado e os filhos destes; do irmão e o sobrinho recém-nascido; e de seus próprios filhos, Paola e Diego. Imagens que, uma vez reunidas, dão vida àquelas pessoas, em arranjos ora solitários, ora coletivos; ora sincrônicos ora diacrônicos. Paola e Diego são os principais protagonistas, com fotografias desde o nascimento até o momento atual. Os intervalos de tempo entre as fotos da menina, mais velha, são maiores do que entre as do menino. Falando sobre essas fotografias, Sandra nos mostrou a importância de seus filhos e dessas fotografias em sua vida:

“Eles são minha vida, são tudo para mim. Eu gosto de ficar olhando, fazendo carinho, e... depois, eu estou na cadeia, né? É 
o jeito que eu tenho para ficar com eles. Vejo o tamanho deles, como eles estão, se estão fortes, bonitos! Sempre estão, né?! [risos] A minha filha já está com os peitinhos crescendo, olha! É o único jeito que a gente tem... eles não estão aqui para me visitar. Eu quero acompanhar eles cresceeennddoooo! E...[pausa]. Você pode me achar doida, mas tem dia, quando estou triste ou com saudades (esses dias que a gente passa aqui dentro!) aí eu fico com eles, faço carinho no rosto deles... chego a sentir a pele e o cheiro deles [risos]. É sério! Eu sinto mesmo!".

A fala de Sandra mostra que, para as estrangeiras na PFC, as fotografias não são meras imagens ou objetos de troca, antes se tornam parte constitutiva das relações transnacionais: elas mantêm viva, na lembrança das deslocadas, uma vida familiar idealizada e temporariamente suspensa pela separação transnacional; mantêm vivas também as obrigações e responsabilidades dos familiares entre si. No caso das estrangeiras, essa agência das fotografias está diretamente relacionada à sua capacidade de corporificar os fotografados. Acompanhar, por meio das fotografias, o desenvolvimento físico, fazer carinho, sentir a pele e o cheiro são práticas de produção de presença, na ausência instaurada pelo aprisionamento e por uma série de limitações comunicacionais; práticas realizadas por presas que, comumente sem qualquer chance de receber visitas, buscam tecer presenças dos familiares e amigas do lado de cá, e a sua própria presença do lado de lá.

Numa reflexão sobre a pragmática do ato fotográfico, Dubois abordou brevemente o "álbum de família", no esforço de desvendar, na própria natureza desse artefato, aquilo que lhe imputa grande importância:

“[O] que confere tamanho valor a esses álbuns não são nem os conteúdos representados neles próprios, nem as qualidades plásticas ou estéticas da composição, nem o grau de semelhança ou de realismo das chapas, mas sua dimensão pragmática, seu estatuto de índice, seu peso irredutível de referência, o fato de se tratar de verdadeiros traços físicos [aqui chamados de "rastros"] de pessoas singulares que estiveram ali e que têm relações particulares com aqueles que olham as fotos" (DUBOIS, 2006, p.80).

Em contraste com ícones e símbolos, que se vinculam a seus referentes por semelhança ou convenção, a concepção peirceana de índice adotada por Dubois (2006, p.61) implica uma "relação de conexão real, de contiguidade 
física, de copresença imediata [do índice] com seu referente (sua causa)".

Para além da inegável importância dos conteúdos representados nas fotografias para as estrangeiras no acompanhamento do desenvolvimento físico dos filhos e da dinâmica familiar, buscamos destacar aqui o seu estatuto indicial, i.e., a sua capacidade de corporificar e reunir os familiares por meio de seus traços e rastros, de (re)compor a coesão familiar e de imprimir certa dinâmica temporal (diacrônica) à família e à prisão. $\mathrm{O}$ recebimento de fotografias do exterior com alguma frequência contribui decisivamente para essa concretização indicial de presenças remotas no contexto intramuros. No cotidiano repetitivo e maçante da prisão, no qual a presença dos familiares não está dada de antemão, mas precisa ser habilmente produzida, fotos antigas, quando desacompanhadas de atualizações por fotos mais recentes, podem intensificar a sensação de abandono entre as presas - que, já presas num espaço carcerário, se sentem aprisionadas também num tempo congelado que não passa. Isso ficou muito claro no caso relatado pela búlgara Dorina quando estava deixando a PFC:

\begin{abstract}
"As fotos são muito importantes para quem está presa e não recebe visita, você não faz ideia. Eu fiquei sem ver meus filhos quase 5 anos, porque minha família só me mandou foto antiga, do tempo em que eu ainda estava lá. Aí, quando eles me mandaram uma dele com sete anos, já no finalzinho da minha cadeia, eu quase morri! Eu não podia acreditar: meu bebê que deixei com dois anos estava daquele tamanho! Chorei de alegria... e de tristeza também. Doeu muito ver que perdi toda essa fase da vida dele. Não sei bem como explicar, mas vira uma companhia. Tem mulher que chega a sentir a pele, o cheiro da pessoa na foto! Não foi meu caso. Eu só tinha foto antiga e acabava deixando as minhas guardadas. Ficava só com as cartas mesmo e olhava as fotos só de vez em quando. Mas era ruim. Elas me davam a sensação de que minha família tinha parado no tempo das fotos. Junta isso com o tempo na cadeia, que não passa nunca... já viu, né? Parecia que tudo estava parado. Todos os dias iguais aqui dentro, aí meus filhos sempre iguais nas fotos. Parecia que eles tinham me abandonado e eu só ficava com aquela lembrança antiga. Mas aí vinham as cartas e diziam que não. Era muito ruim, dá vontade de chorar só de lembrar. Por isso que eu guardei as fotos e não vi mais".
\end{abstract}

Além de receber, as presas também podem enviar suas presenças em fotografias aos familiares. Foi numa foto com as parceiras que Sandra 
foi vista pela primeira vez por Ernesto, colombiano que cumpre pena na "penitenciária do Itaí", 3 unidade exclusiva para homens estrangeiros, localizada a cerca de 300 quilômetros de São Paulo. Uma parceira de Sandra enviou ao namorado, também preso no Itaí, uma correspondência contendo uma foto sua com outras presas, dentre elas, Sandra. Essa imagem circulou pelas mãos dos parceiros do namorado da moça, seguindo uma prática do mercado de "casos e casamentos" (PADOVANI, 2015) entremuros. Ao ver Sandra, achá-la atraente e descobrir que ela era solteira e sua conterrânea, Ernesto logo recrutou o casal de namorados para promover o contato dele com a colombiana, via cartas e telefonemas via celular. E funcionou. Sandra aceitou a investida do rapaz, a despeito do caso que ela mantinha com uma brasileira lá dentro.

O pedido de casamento não tardou a chegar, atrelado à promessa de o pretendente contribuir para o sustento dos filhos da moça. Foi a distância entremuros que selou o matrimônio ${ }^{4}$, relação que estará a todo tempo condicionada, porém não restrita, aos interesses da colombiana de sustentar os filhos no aprisionamento, e se fazer mãe por meio desse sustento. É interessante observar como os mesmos muros prisionais que separaram Sandra de seu filho, agora, a religam a ele por meio de outros agentes: um amigo do seu novo marido, residente em Cali, passou a frequentar a casa da sua irmã para entregar o dinheiro destinado aos custos dos seus filhos. Experimentando com as potencialidades das fronteiras prisionais e nacionais, dos arranjos afetivos-sexuais e maternos, Sandra conseguia afastar o tempo familiar e o prisional de seus estados sólidos (de congelamento) a partir de fluxos intra, entre e extramuros. Fluxos desdobrados em mercadorias, dinheiro e fotografias; feitos de "ajudas", cuidados, deveres, direitos, interesses e afetos que, uma vez constituídos na

\footnotetext{
3 "Penitenciária do Itaí" é a forma como as estrangeiras na PFC se referem à Penitenciária Cabo PM Marcelo Pires da Silva, localizada em Itaí (SP).

${ }^{4}$ Lago (2014, p.76) narra algo bastante semelhante, quando uma de suas personagens presas fala da dimensão produtiva dos muros em um "relacionamento que não apenas se mantém a despeito das distâncias criadas pela prisão, mas que se fortalece diante dessas mesmas distâncias". Como notado por Ferreira (2005, p. 22): "Quando limites deixam de ser vistos como separações e passam a ser vistos como a produção mesma daquilo que separam, então as relações que eles mediam deixam de ser relações entre dois polos que preexistem à própria relação (...) e passam a ser relações entre outras relações que não precisariam existir enquanto tais antes de serem relacionadas".
} 
separação da prisão, recusaram-se à contenção; atravessaram os limites dos muros, das "coisas", dos corpos e das relações, e produziram presenças.

\section{Carta: Copresença espacial, com defasagem temporal}

A sul-africana Maretha vinha recebendo ameaças brandas de outras sulafricanas em seu pavilhão, em função do fato de ter delatado, às justiças brasileira e sul-africana, um nigeriano e autoridades de seu país envolvidos em seu aliciamento para o tráfico. Muito embora a moça compartilhasse sua rotina e seus sentimentos mais íntimos com a mãe por meio de cartas digitalizadas enviadas por e-mail, ${ }^{5}$ achou conveniente não comentar essa tensão intramuros - já bastavam as ameaças que vinham obrigando a senhora de quase 70 anos a mudar de casa, e até de cidade. Mas a caligrafia de Maretha denunciava à sua mãe seu estado emocional, independentemente do conteúdo das mensagens. Se a escrita estava pequena e apertada, a mãe sabia que ela se encontrava triste; se estava tremida e corrida, que ela estava nervosa ou apreensiva; e se estava bem arredondada, grande e simétrica, a mãe ficava tranquila, a filha passava bem.

As cartas digitalizadas carregam índices: signos, tais como a caligrafia, que mantêm uma ligação material e existencial com a remetente. Índices que, ao atravessarem a distância prisional transnacional e entrarem em relação com a mãe destinatária, têm suas informações transformadas em ação: atualizam a presença da remetente diante da destinatária no momento em que esta lê os indícios afetivos inscritos no conteúdo e na caligrafia. Como em Gell (1998), a caligrafia se torna um índice mediador de agências, um rastro indicial de materialidade corporal, um transdutor da ação efetuada por uma pessoa através de seu corpo sobre outras materialidades.

“Eu e minha mãe estamos sempre juntas! Ela me manda e-mail e carta pelo menos duas vezes na semana, me liga, me manda sedex... sedex nem sempre, porque é muito caro. Eu também

\footnotetext{
${ }^{5}$ Apesar de o uso da internet nas prisões brasileiras ser legalmente proibido, a situação excepcional de isolamento transnacional das estrangeiras na PFC permitiu que se desenvolvesse, para elas, uma forma mediada de correspondência eletrônica: semanalmente, agentes do Instituto Terra Trabalho e Cidadania (ITTC, organização civil de direitos humanos), digitalizam e enviam - por e-mail - cartas escritas por essas mulheres e lhes entregam, em forma impressa, as respostas recebidas.
} 
escrevo sempre, mando fotos de vez em quando, mas ela consegue me ver mesmo [nas cartas digitalizadas enviadas] nos e-mails. Ela me vê mesmo, como se estivesse olhando nos meus olhos. Eu sinto isso quando escrevo. Aí nem adianta eu mentir, porque ela sabe como eu estou só pela minha letra".

Muito embora seja a materialidade da carta a principal portadora dessa presença indiciária distribuída e acessível aos sentidos (cf. PADOVANI, 2015), o seu pleno potencial mediador passa, via de regra, pela escrita e pela leitura. Por isso, quando cartas são usadas para mediar interações com crianças não alfabetizadas, além de acionarem outros sentidos (e.g.: cheiro, textura, cor, desenhos, beijos, rabiscos etc.), elas ainda podem mobilizar outros familiares para a leitura. A colombiana Sandra, por exemplo, além dos presentes comprados para os filhos em seu nome (maneira de se tornar, literalmente, "presente", sem depender da mediação escrita), sempre destina para o menino uma parte das cartas escritas à sua mãe, filha ou irmã.

\begin{abstract}
“Ele ainda não tinha um ano quando eu comecei a fazer isso. Pedi a elas para chamarem ele de "gorducho" toda vez que eu mandar recado para ele e dizer: "a mamãe quer falar com você". Aí elas leem o que eu escrevi. O truque está na família, principalmente na minha mãe. Eu tenho certeza que hoje ele sabe quem eu sou. Se eu encontrasse com ele na rua, ele me reconheceria. Como por quê? Ora, eu sei a mãe e a família que tenho. Minha mãe fica atrás dele lendo as cartas, mostrando minhas fotos e dizendo 'está aqui a mamãe, é a mamãe do gorducho'. Minha filha diz que não aguenta mais ver a vó com uma foto na mão mostrando pra ele. Ela me contou que a Milagros [sua mãe] colocou umas fotografias minhas e uns desenhos que fiz e mandei para ele na cômoda perto da caminha dele. Ele acorda e dorme me vendo. Minha irmã é outra que fica fazendo essas coisas. Ela adora inventar historinhas para ele e eu sempre apareço como uma das personagens. Pois é, Bruna, virei personagem de história!".
\end{abstract}

A copresença entre mãe e filho é produzida, assim, pela leitura da carta pela avó. No ato presente de redação da carta, Sandra interage com sua mãe e seu filho, apesar de estes estarem situados, não apenas em outro lugar, mas também em outro tempo, no futuro. Milagros, por sua vez, no ato presente de leitura da carta para seu neto, coloca este em interação com uma Sandra que, apesar de palpável nos índices materiais da carta, não 
está acessível no presente, mas apenas como rastro passado. O presente do destinatário é o futuro do remetente, e o presente deste é o passado daquele, defasagem que inviabiliza uma interação instantânea entre ambos. Assim como em Latour (2005, p.12), a tarefa de "rastrear associações" (i.e., de torná-las concretamente acessíveis à ação e à imaginação) envolve a habilidade de "se mover entre sistemas de referência e retomar alguma forma de comensurabilidade entre rastros provenientes de sistemas se movendo a velocidades e acelerações muito diferentes" ${ }^{\prime \prime}$.

(Re)ler o conteúdo, acompanhar o desenvolvimento físico, fazer carinho, enviar fotografias e dormir com elas, dar e receber beijos, tocar a mão e sentir o cheiro, são práticas de produção presencial entre lá e cá. Práticas adaptadas para as estrangeiras na PFC criarem e manterem relações em torno, e através, da maternidade; práticas que ativam outros modos possíveis de presença, para além da contiguidade física direta; práticas que desempenham, pela mobilização de mediadores, e com periodicidade variável, a presença temporalmente defasada do remetente que deseja estar com o destinatário. Em suma, práticas que sugerem um modo de existência epistolar do remetente, capaz de produzir uma espécie de "presença ausente" diante do destinatário - "como se fosse uma visita". 7

\section{“Sedex": Agência distribuída}

"Sedex" é o nome dado a um pacote cheio de mercadorias enviado às estrangeiras na PFC, geralmente por seus familiares, utilizando o serviço homônimo dos Correios. A tailandesa Kanokwan, autoproclamada "rainha do sedex", nunca recebeu visita de familiares na PFC, mas vem tendo o privilégio de receber "sedex" da Tailândia. Ansiosamente aguardados, esses pacotes demoram cerca de dois meses para chegar e levam "coisas" raras para dentro da prisão; mercadorias de qualidades e de marcas dificilmente encontradas no comércio de São Paulo, que carregam em sua materialidade elementos do ambiente familiar da moça: langeries, chinelos,

\footnotetext{
"Bruno (2012) oferece uma importante releitura da concepção latouriana de "rastro".

${ }^{7}$ A expressão "como se fosse uma visita", recorrente na fala de parte das estrangeiras quando o assunto são as correspondências, indica que as missivas são visitas, mas visitas mediadas por papel, que podem ser tocadas, cheiradas, beijadas, observadas e guardadas, mas que não interagem com a imediacidade da presença física direta.
} 
cadernos, canetas coloridas, shampoos, condicionadores, cremes corporais, balas de goma, além da carta que as acompanha. "Coisas" que fazem chegar à penitenciária cheiros, sabores, cores, imagens, texturas e lembranças, fragmentos de sua vida pregressa; que carregam também a presença e o cuidado da mãe e da irmã nas etapas de envio do pacote - desde a prática de economizar o dinheiro, passando pela compra das mercadorias, o preparo e o envio do embrulho, até o compartilhamento (via telefonemas, cartas ou e-mails) da alegria da destinatária presa, quando finalmente o recebe.

"Ah menina, toda vez que chega o sedex eu fico me achando. Me
sinto a maior rainha. E não é da cocada preta, não [risos]. Fico
me achando, porque... quantas estrangeiras têm esse privilégio?
Eu fico pensando no carinho da minha mãe e da minha irmã
comprando tudo, preparando tudo para mim, sabe? Eu sei que
elas estão deixando de gastar com elas pra poder me mandar, essa
é a parte triste. A minha família não é rica pra mandar sedex...
é muito caro. Aí as meninas aqui ficam tudo puxando meu
saco, sendo boazinha comigo para eu dividir com elas as coisas.
Principalmente as tailandesas, né, que querem usar as coisas do
nosso país".

Além de garantir às estrangeiras uma posição privilegiada na produção da estratificação social interna à $\mathrm{PFC}, \mathrm{o}$ "sedex" exprime também um meio de acesso (valioso e escasso) delas aos seus respectivos locais de origem. Em outros termos, o "sedex" produz uma dupla mobilidade: social, na forma de deslocamentos verticais nas hierarquias intramuros; e espaço-temporal, na forma de valiosos deslocamentos horizontais para além dos muros da PFC. Mas mais importante ainda, os conteúdos dos "sedex" desdobram múltiplas presenças, relações, cuidados, afetos e lugares, compondo alguns nós do ambiente familiar distante.

Os pijamas, por exemplo, que embalam as noites de sono de Kanokwan há anos, foram e continuam sendo um dos mimos costumeiros de sua mãe, comprados sempre na mesma loja. Os chinelos lá do mercado do bairro, apesar de vagabundos, são tão confortáveis para ficar em casa que a tailandesa tinha uma coleção deles espalhados pelos cômodos da casa. Já os cadernos, vendidos em tudo quanto é canto, carregam em sua simplicidade ordinária pedaços do cotidiano mais banal de Bangkok. Para não falar dos cremes corporais, shampoos e condicionadores que, ao som da playlist de seu celular, compuseram o ritual doméstico matinal em seus últimos 
anos na casa de sua mãe; sempre das mesmas marcas, trazem detalhes do banheiro e das reclamações da sua avó sobre a mistura de seus aromas. Por fim, as balas azedas de goma, seu vício! Companheiras de todas as horas, marcaram os sabores e dissabores dos deslocamentos de Kanokwan pelos quatro cantos da sua "cidade dos anjos".

Porém, o ambiente familiar produzido no encontro de Kanokwan com seu "sedex" já não corresponde exatamente ao seu estado presente: a loja dos pijamas mudou de dono e endereço; seu quarto ganhou novos ares com a chegada da sobrinha; sua irmã voltou para casa depois de uma separação; sua mãe envelheceu 20 anos de dores familiares; e seus avós partiram de velhice. Aquela Kanokwan de quatro anos atrás não está mais lá... nem cá! Ela vive num ambiente familiar que existe em suas lembranças e nas materialidades dos rastros que as evocam. Assim como no caso das cartas, uma defasagem temporal é o preço pago pela contiguidade física dos rastros.

\section{Celular: Copresença temporal, com defasagem espacial}

A posse, o uso ou o fornecimento de aparelhos celulares, rádios ou similares são definidos como falta grave pela Lei 11.466 de 28 de março de 2007. Tais atos podem acarretar a perda do trabalho e dos seus dias remidos, a permanência de até um mês no "castigo", a suspensão, durante os seis meses seguintes, dos possíveis pedidos de liberdade-condicional e de semiaberto e, uma vez já progredido de regime, pode gerar o cancelamento deste e o retorno ao regime fechado. Em caso de ingresso, promoção, intermediação, auxílio ou facilitação da entrada desses aparelhos em unidades prisionais, sem a devida autorização legal, tais atos podem levar, de acordo com a Lei 12.012 de 06 de agosto de 2012, a uma pena de prisão de três meses a um ano. Como se sabe, nada disso diminui a importância dos aparelhos nas práticas e políticas vinculadas ao "mundo do crime" (cf. BIONDI; MARQUES, 2010; DIAS, 2011; FELTRAN, 2010; MALLART, 2014).

Nas prisões femininas, o celular é usado, apesar de todos os impedimentos e implicações, para desempenhar, à distância e na cadeia, a relação imperiosa da maternidade. "O problemaé que o governo brasileiro acha que o celular é usado só para PCC, crime, rebelião", dizem as estrangeiras na PFC. Conforme constatado em Bumachar (2011; 2012), a mediação de aparelhos celulares sempre em associação com algum(ns) outro(s) rastro(s) - é fundamental para "se fazer mãe" de dentro da prisão. 
Entendemos que essa relação intrínseca entre celular e maternidade se deve à importância da produção da presença mais direta, simultânea e espontânea possível. Ou seja, se levarmos em conta que o cuidado presencial é amplamente considerado um dos pilares do exercício da maternidade (cf. HAIRSTON, 2007; VEREA, 2007), compreendemos as motivações das estrangeiras na busca de meios capazes de produzir uma interação mais sincrônica e espontânea com seus filhos. A colombiana Sandra mostrou isso muito claramente:

“Tem coisas que só a mãe mesmo resolve. Minha filha foi criada por mim, só eu e ela em casa. De repente ela fica sabendo que a mãe está presa, pensa que a mãe é uma criminosa e que vai ficar na cadeia do Brasil sabe lá por quanto tempo. Ah, Bruna, a revolta bateu! A menina ficou revoltada e eu sei que a culpa é minha. Minha mãe me escreveu contando que ela tinha fugido de casa... vai minha mãe buscar Paola na casa da amiguinha! Depois, decidiu que não ia mais para a escola. Aí eu disse chega! Não pensei em nada de castigo, de trabalho, de remissão. Tinha que resolver a situação. Você acha que você resolve uma coisa dessa por e-mail, por carta? Claro que não! As mensagens ajudam [...], são muito importantes. Deus me livre ficar sem elas! Mas na hora do problema mesmo, a menina vai me esperar em casa para ler alguma coisa? Aí de noite, depois da tranca, contei para minha parceira a situação. Eu nem precisei pedir o celular emprestado para ela. Ela já me ofereceu em troca de uns maços [de cigarro]. [...] Aí, liguei para minha mãe e pedi para falar com Paola. Aí falei para ela ir pro quarto e fechar a porta pra gente conversar em particular. Quando a gente acabou, pedi pra ela chamar a avó, colocar o celular no viva-voz pra gente conversar as três. Aí pronto, problema resolvido! E criado também [risos]. [...] [P]orque tomei gosto pela coisa, tipo vício. É, porque eu gostei mesmo, me senti sendo mãe de verdade, sabe? Liguei no outro dia para saber como estava a situação, depois mais outro, mais outro... até que combinei com minha mãe que eu ligaria pra elas todos os sábados de tarde, pra elas sempre ficarem junto com o celular nesse período. Porque é a gente que liga sempre, né, daqui para lá. Aí falava com os três, era uma festa. Toda vez que eu ligava para falar com elas, minha mãe colocava o gorducho na linha. Ela fez isso pela primeira vez quando ele ainda não sabia falar nenhuma palavra, ficava só gritando e falando na língua dos bebês, sabe? [Sandra imita o balbuciar dos bebês]. Minha mãe segurava o telefone no ouvido dele. Eu falava com ele: 'filho, aqui é a mamãe. A mamãe ama o gorducho!'. Essas coisas, para ele conhecer minha 
voz. Minha mãe ficava do outro lado dizendo: 'fala com sua mãe, filho, fala! Alô, mamãe! Fala com ela!'."

Sentimentos como culpa, impotência, vergonha, tristeza e frustração fazem parte do exercício da maternidade entre presas (cf. BAUNACH, 1985; KARVELI et al., 2012; LOPES, 2004; MATOS; MACHADO, 2007; MORASH; SCHRAM, 2002). Isso tende a se potencializar quando os filhos enfrentam dificuldades do lado de fora e as mães não conseguem assisti-los diretamente (GRANJA; CUNHA; MACHADO, 2013, 2014). Como vimos, no caso de Sandra, os aparelhos foram fundamentais para ela promover tal assistência no exato momento do surgimento do problema, garantindo-lhe a atualização de sua identidade materna, e a solução (sempre temporária) da ambivalência entre sua vida na prisão e a vida familiar no país de origem.

Através dos telefonemas, Sandra conseguiu amenizar a culpa que aflige muitas presas diante do mau comportamento dos filhos (cf. CUNHA; GRANJA, 2014) e se sentir atuando como "mãe de verdade". Também garantiu uma forma de sociabilidade materna e familiar mais sincrônica - inacessível à mediação de cartas, e-mails e outros corpos que demoram dias, semanas ou meses para transpor a distância espacial entre remetente e destinatário -, resolvendo assim o problema do mau comportamento de Paola e fazendo-se conhecer pelo pequeno Diego na dimensão vocal.

\section{Temporalidades em conflito: Graus de presença}

A notícia chegou à sul-africana Nonhlanhla via e-mail: seu marido Anella e outros dois seguranças foram assassinados durante um assalto à casa de câmbio onde trabalhavam. Ela ficou inconsolável. Gritou, chorou e, por fim, silenciou. Era preciso aceitar a realidade: seu marido havia morrido e ponto final. Ponto final não, reticências... que se formavam a cada três cartas semanais que ainda recebia dele.

Foi o desejo de produzir uma interação mais contínua, sem os altos custos do celular, que motivou o casal a manipular o tempo, se escrevendo três vezes por semana. ${ }^{8}$ Dessa forma, passado o recebimento da primeira carta,

\footnotetext{
${ }^{8}$ A produção interacional, e não tecnológica, de sincronicidade, foi demonstrada também em Rettie (2009).
} 
o intervalo de quase um mês entre o envio e o recebimento foi suprimido pelo contínuo fluxo das correspondências conseguintes (cf. Figura 1). A modulação da velocidade das cartas operada pela técnica de envio modificou as percepções estabilizadas de um tempo único, possibilitando aos dois a produção e o compartilhamento de um presente conjugal e familiar - não pela sincronicidade intangível produzida pelo celular, mas pelo engenhoso preenchimento da defasagem temporal da carta pela materialidade tangível dos rastros epistolares, acessíveis nos atos de cheirar, ler, observar, tocar e carregar os papéis e tudo aquilo inscrito nele ou anexado a ele. Uma copresença que ganha vida num tempo passado-presente, e num espaço dentro-fora, rearranjando estrategicamente parâmetros espaço-temporais, e explorando ao máximo as suas potencialidades de mediação. 
Figura 1 - Esquema temporal da produção de copresença entre $[A] \mathrm{e}$ $[B]$, por meio de 3 cartas semanais, interrompida pela morte de $[A]$ e pelo e-mail de $[C]$. O tempo corresponde ao cruzamento das setas paralelas verticais [A] e [B], pelas linhas paralelas horizontais, indo de [1] a [27], representando os instantes de envio e/ou recebimento das cartas: cada 3 linhas/cartas correspondem a 1 semana (de [S1] a [S9]); e cada 4 semanas a 1 mês ([M1, M2 e M3]). As cartas demoram 3 semanas para percorrer a distância entre $[A]$ e $[B]$, e são identificáveis pelo nome do remetente seguido do número correspondente à linha do envio. Assim: a última carta enviada por [A] é a [A16]; e a primeira carta de [B] que não foi mais recebida por $[A]$, mas sim por $[C]$, é a [B8]. O e-mail, seta pontilhada que sai de [C] em [16], demora 1 semana para chegar, indiretamente, a $[B]$, em [19]. Podemos notar que: (1) existe um intervalo inicial de 3 semanas [S1, S2 e S3] entre o início do envio das cartas pelos remetentes e o início do seu recebimento pelos destinatários; (2) a copresença de $[A]$ e $[B]$ existiu, para $[B]$, entre o envio das cartas [B10] e [B19], ao passo que, para $[A]$, ela durou uma semana a menos, entre o envio das cartas [A10] e [A16]; (3) apesar de [C] ter recebido 12 cartas de $[B]$ após a morte de $[A]$ (de [B8] a [B19]), apenas 3 delas foram enviadas por $[B]$ após a morte de [A] ([B17, B18 e B19]); (4) das 9 cartas que $[B]$ recebeu de $[A]$ após sua morte, apenas as 3 primeiras ainda produziram copresença ([A8, A9 e A10]), efeito que se inverteu nas cartas de [A11] a [A16], que chegaram a [B] depois do e-mail enviado por [C] em [16]. Este esquema busca ilustrar, de maneira abstrata e sem correspondência temporal completa, aspectos do caso da produção epistolar de copresença espaço-temporal entre Nonhlanhla e Anella.

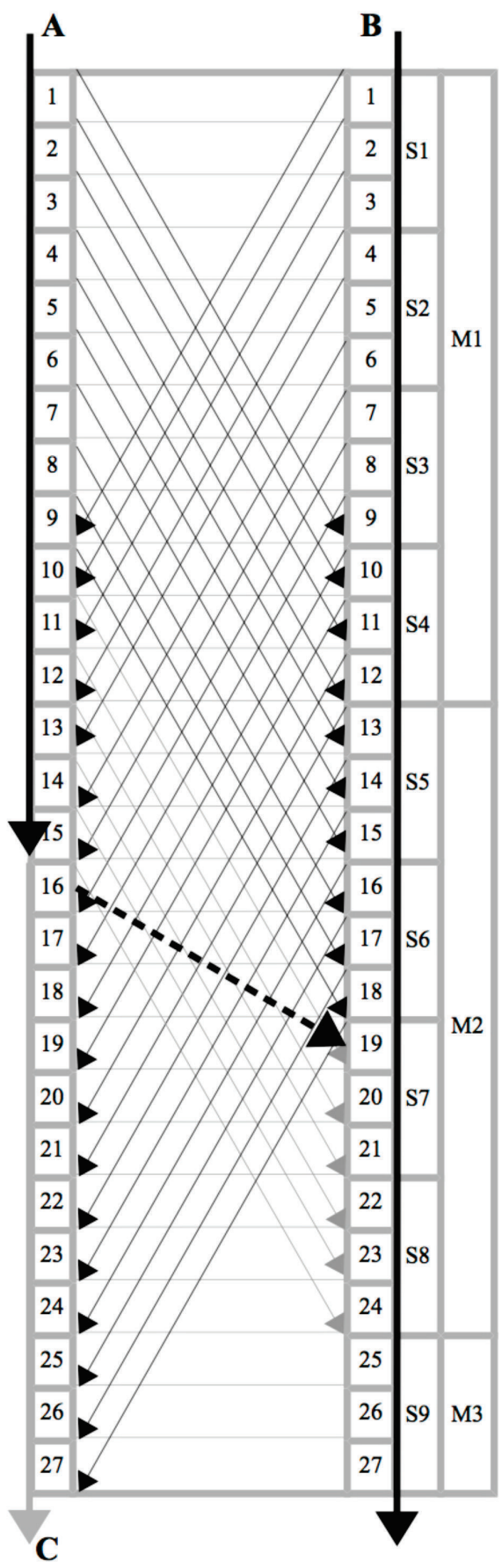


As cartas de Anella estavam seguindo tranquilamente rumo à prisão, com a finalidade de concretizar a presença dele junto à esposa presa, quando, de repente, foram tomadas de assalto pelo e-mail da irmã da sulafricana. Com uma velocidade muito inferior à do e-mail, as cartas não tiveram condições técnicas para reagir à situação - exatamente como Anella diante da munição do assaltante. Uma vez atingidas, perderam sua força vital e não puderam mais produzir presenças. Restou-lhes apenas levar para dentro da prisão os últimos suspiros de uma vida conjugal passada.

Nessas duas associações paralelas, munição-Anella e e-mail-cartas, o futuro e o presente do casal foram aniquilados. Não há mais um futuro conjugal possível no exterior da prisão, tampouco presente (epistolar) no seu interior; há apenas passado. A vida de Nonhlanhla com Anella se torna pretérita e invivível, e a prisão, um "atraso de vida" - metáfora intramuros bastante popular que ganha literalidade nesse episódio. Resultado: algo próximo da sucumbência... se não fosse seu filho, Sibusiso. Agora seria a vez de o menino dar vida à mãe, ajudando-a a remendar seu corpo e sua existência com fios sociotécnicos de afeto e cuidado. Sem o pai, como ficaria o menino? Com quem ele viveria? Como lidaria com a mudança de casa? Seria melhor ele permanecer sob os cuidados de Phumeza, uma vizinha amiga da mãe, ou morar com Khanyisile, a irmã caçula da presa residente numa cidade próxima? Estas foram as primeiras questões que ocuparam Nonhlanhla a alguns passos da completa sucumbência. Ela precisava cuidar do filho e estar ao lado dele, não poderia se render à sua dor e abandoná-lo neste momento.

Sibusiso acabou permanecendo com a vizinha, tendo sua tia ficado responsável por visitá-lo ou levá-lo para sua casa aos finais de semana. Para isso funcionar, Nonhlanhla precisou intensificar o envio de e-mails semanais, e as chamadas telefônicas tiveram que se tornar quase diárias. $\mathrm{O}$ interessante aqui é como o extrapolamento do binômio mãe-filho, negociado na distância espaço-temporal, gerou uma situação ambígua e inédita para Nonhlanhla: se, por um lado, o compartilhar das responsabilidades estendeu o grupo de parentesco à vizinha e, com isso, minimizou o medo materno de ter Sibusiso roubado ou maltratado; por outro lado, criou fofocas, intrigas e mal-entendidos entre suas três responsáveis.

"Outro dia gritei com Khanyisile e desliguei o telefone na cara dela. Fui tentar resolver um problema dela com Phumeza, porque uma falava uma coisa de Sibusiso e a outra, outra, e acabei 
entrando na briga. Eu que sou a mãe, que sempre cuidei dele. Eu que sei o que é melhor para ele. Mas às vezes ela não entende isso, quer fazer tudo do jeito dela. Mas logo depois liguei de novo e deixei as coisas do jeito dela mesmo... que raiva! Não posso ficar sem a ajuda dela...".

Como bem expressaram Granja, Cunha e Machado (2014, p.1223-4), se, por um lado, as mães presas "precisam permitir alguma autonomia àqueles envolvidos no cuidado cotidiano com seus filhos", por outro, elas "exigem manter seu papel como principais responsáveis por seus filhos, atuando centralmente em decisões sobre seu comportamento, educação e disciplina". De fato, embora Nonhlanhla reivindicasse seu papel de principal responsável pelo menino, não podia prescindir desse novo arranjo distribuído, composto com cautela e atenção às vontades e autoridades das cuidadoras envolvidas. A sincronicidade da interação mediada por celular revela, na sua intangibilidade (nenhum rastro permanece, para as estrangeiras, ao término da ligação), a distância espacial que separa os interlocutores. O corpo de Nonhlanhla definitivamente não está onde precisa estar, exceto por sua voz, que ela se esforça para torná-la presente.

\section{Agência distribuída e produção de copresença na distância prisional transnacional}

Como tornar presente o ausente? Como se fazer presente onde não se está? São questões ligadas tanto à migração transnacional quanto à experiência prisional no exterior. Na literatura transnacional, por exemplo, termos como "long distance intimacy" (PARREÑAS, 2005), "proximidade à distância" (LOBO, 2006), "physical distance" (McKENZIE; MENJÍVAR, 2011) e "care at a distance" (LEIFSEN; TYMCZUK, 2012) são acionados para sugerir uma presença/ proximidade "digital" dos familiares, definida em oposição àquela supostamente "real". Delineada nos limites do corpo/ organismo humano, essa presença/proximidade digital é compreendida como capaz de conectar os indivíduos em comunicação na distância transnacional através de um intermediário, os artefatos ou objetos técnicos. Aprofundando-se na questão, Madianou e Miller (2012) cunharam o termo "polimídia" para definir o ambiente no qual as "mídias" medeiam as (e se definem a partir das) relações entre os indivíduos separados pela distância transnacional. 
Algo semelhante ocorre nos estudos prisionais quando, por exemplo, as cartas são definidas como presenças "quase físicas" (ROSA, 2008), "adaptadas" (BRITO, 2007) ou "substitutas do corpo" (COMFORT, 2007b). Tal como na literatura transnacional, essas três expressões questionam o isolamento das fronteiras espaciais (no caso, as prisionais), evidenciando como, através da circulação das epístolas, remetentes e destinatárias(os) garantem certa mobilidade por entre os muros da prisão: o ex-general preso na ditadura militar consegue produzir uma presença "quase física" diante da esposa leitora; mães conseguem exercer uma maternidade "adaptada" dentro da prisão; e maridos presos e suas esposas conseguem "substituir" seus corpos uns diante dos outros.

Assim, tanto no contexto prisional quanto no transnacional, as pessoas e seus limites são entendidos como inquestionavelmente estáveis: as pessoas, que são sempre indivíduos (de)limitados em seus corpos, acionam objetos intermediários, também (de)limitados em suas formas físicas, para se comunicarem entre si; o que varia são os sentidos atribuídos pelos indivíduos a cada um dos agentes (destinatários, remetentes e intermediários). Fundamentados em critérios morfológicos de individuação, tais estudos sugerem um ambiente povoado por "indivíduos possessivos" (MACPHERSON apud HARAWAY, 2011), pessoas com fronteiras totalmente definidas, que se comunicam através de coisas intermediárias ("mídias") sem as alterar e nem serem alteradas por elas, como se os limites físicos de umas jamais pudessem afetar nem serem afetados pelas materialidades, temporalidades e possibilidades de ação das outras. Em resumo, esses estudos tomam as pessoas como indivíduos fechados nos limites de seus corpos, e as coisas como intermediários delimitados em suas materialidades e funcionalidades externas. E é justamente como alternativa a essa perspectiva que este texto apresentou casos concretos de agência distribuída e produção de copresença em redes espaço-temporais de cuidado.

Como vimos, no caso das mulheres estrangeiras presas na PFC, a realização do desejo de estarem presentes onde seus corpos não estão (i.e., junto a seus filhos e familiares) é mediada por um conjunto diverso de rastros: fotografias, e-mails, cartas, telefonemas, dinheiro, mercadorias e outros corpos. Quando associados entre si na interação com o destinatário, tais rastros efetivamente presentificam aspectos tangíveis do remetente para além dos limites de seu organismo, i.e., são "processos tecnicamente mediados de associação" (FERREIRA, 2005) capazes de estender a presença 
do remetente no hiato espaço-temporal que o separa do destinatário, proporcionando-lhes a produção efetiva de copresenças mediadas.

Os variados graus de proximidade, intensidade e simultaneidade envolvidos na produção da copresença estão diretamente ligados aos possíveis modos de gestão sociotécnica das variáveis espaço-temporais. Como vimos, no caso das estrangeiras na PFC, essa gestão pode se desdobrar através de dois movimentos: a produção de copresença espacial com defasagem temporal; e a produção de copresença temporal com defasagem espacial. A produção de copresença espacial é realizada por meio da circulação de materialidades portadoras de rastros capazes de atualizar ações passadas de um remetente-emissor nas ações presentes de um destinatário-receptor (fotografias, cartas, objetos etc.). O tempo é transformado (passado, presente e futuro do remetente e do destinatário são recombinados) para que o espaço possa ser compartilhado (contraído como rastro). Quando, por exemplo, a mãe de Maretha entra em interação com a filha em forma de carta, há uma contração da distância espacial na forma de um rastro compartilhado, que atualiza o ato passado da escrita no ato presente da leitura. Escrevendo uma carta para sua mãe, o "corpo articulado" (LATOUR, 2008) de Maretha inscreve sua presença num suporte material capaz de ativá-la nas mãos de sua mãe, que cartografa sua caligrafia como se estivesse a olhar dentro de seus olhos.

No segundo movimento, a produção de copresença temporal é realizada pela circulação de materialidades portadoras de rastros capazes de atualizar ações presentes de um interlocutor-emissor nas ações presentes de um interlocutor-receptor (sinais eletromagnéticos emitidos e recebidos por aparelhos celulares). Os telefonemas de Sandra para seus filhos, por exemplo, circulam muito mais rapidamente do que os e-mails, as cartas e os presentes, sendo um meio de comunicação particularmente eficaz para ela conhecer e interagir com seu marido preso, com seu filho, bem como para solucionar as fugas residenciais e o abandono escolar da filha. Eficaz também para Nonhlanhla definir o paradeiro do filho após o assassinato de seu marido, por meio de negociações com as duas responsáveis por ele (a irmã e a vizinha). Em ambos os casos, o uso do celular ocorre em situações que demandam copresença temporal, na espontaneidade da interação sincrônica, mais do que copresença espacial na forma de rastros tangíveis.

Podemos falar da produção de copresença como um certo tipo de "vaso comunicante" (GODOI, 2015), operado por uma modulação corporal que conecta o interior e o exterior da prisão, no mesmo instante em que atualiza 
uma separação fundamental entre eles: presenças (indiciais) que medeiam ausências (de organismos), e vice-versa. Distância espaço-temporal a um só tempo instaurada e abolida, na produção de presenças pela conexão física e afetiva entre materialidades distintas de remetentes e destinatários; ou, mais precisamente, por atos executados, tanto por remetentes quanto por destinatários, sobre determinadas materialidades móveis e que, por isso, tornam-se articuladas aos corpos daqueles na articulação com estes. Materialidades em ato, cujos sentidos criam, nutrem, cuidam, controlam, vigiam e normatizam as pessoas e seus corpos na distância prisional transnacional. Em suma, trata-se de copresenças singulares e irredutíveis umas às outras, constitutivas e constituintes de um corpo que é múltiplo sem, contudo, deixar de ser um (MOL, 2002).

E é a partir dessas copresenças que as estrangeiras na PFC buscam se fazer em torno e através da maternidade. Mulheres que se transformam para manter seus vínculos; que se transmutam numa rede sociotécnica (LATOUR, 1994) para preservar a responsabilidade sobre os filhos e manter o cuidado presencial materno sob o domínio predominantemente feminino; que rearranjam fronteiras espaço-temporais para multiplicar os fios constitutivos e constituintes da maternidade. É a partir desses rearranjos que essas mulheres criam cotidianamente condições espaço-temporais para nutrir (e também serem nutridas de) cuidados e afetos dos filhos e demais familiares numa nova "gramática do pertencimento" (BELELI; MISKOLCI, 2015). Articulam-se em emaranhados compostos por agentes e unidades (familiares, estatais e não governamentais) e diversas materialidades, para garantir os meios de execução de certas práticas presenciais (maternas e domésticas) bastante corriqueiras, mas nada banais na distância prisional transnacional. Criam estratégias para garantir melhores condições de vida e para sanar sentimentos como culpa, impotência e solidão, produzindo um espaço de interação entre o interior e o exterior da prisão a partir do qual lhes seja possível atuar e se perceber como "boas mães" (CUNHA, 1994; BRITO, 2007) ou, como preferem dizer, como "mães de verdade". 


\section{Referências}

ANGARITA, Andreina.

(2008). Drogas, cárcel y género en Ecuador: la experiencia de mujeres mulas. Equador, Flacso.

BARBOSA, Antonio Rafael.

(2005). Prender e dar fuga: biopolítica, tráfico de drogas e sistema penitenciário no Rio de Janeiro. Tese de Doutorado em Antropologia Social apresentada ao Museu Nacional (MN) da Universidade Federal do Rio de Janeiro (UFRJ).

BAUNACH, Phyllis.

(1985). Mothers in Prison. New Brunswick / New Jersey, Transaction Books.

BELELI, Iara; MISKOLCI, Richard.

(2015). Apresentação. Cadernos Pagu, n. 44, p.7-11.

BIONDI, Karina; MARQUES, Adalton.

(2010). Memória e Historicidade em dois comandos prisionais. Lua Nova, n. 79, p.3970.

BRITO, Mirela Alves de.

(2007). 0 Caldo na Panela de Pressão: um olhar etnográfico sobre o presídio para mulheres em Florianópolis. Dissertação de Mestrado em Antropologia Social apresentada a Universidade Federal de Santa Catarina (UFSC).

BRUNO, Fernanda.

(2012). Rastros digitais sob a perspectiva da teoria ator-rede. Revista FAMECOS, v. 19, n. 3, p.681-704.

BUMACHAR, Bruna Louzada.

(2015). No emaranhado prisional transnacional: o exercício da maternidade entre estrangeiras presas em São Paulo. In: Sílvia Gomes; Rafaela Granja. (Orgs.); Mulheres e crime - perspectiva sobre intervenção, violência e reclusão. 1ed. Portugal, Edições Húmus.

(2012). Por meus filhos: usos das tecnologias de comunicação entre estrangeiras presas em São Paulo. In: Denise Cogo; Mohammed
ElHajji; Amparo Huertas (Orgs.); Diásporas, migrações, tecnologias da comunicação $e$ identidades transnacionais. 1ed. Barcelona, Institut de la Comunicació, Universitat Autònoma de Barcelona.

(2011). Migração e novas mídias: um diálogo sobre a experiência familiar transnacional de estrangeiras presas em São Paulo e de trabalhadoras filipinas residentes em Londres. Revista Cronos, v. 12, p. 75-95.

BUMACHAR, Bruna; VICENTIN, D. J.; KANASHIRO, M. M.

(2013). Mobile phone use in Brazilian prisons. In: Annual Meeting of the Society of Social Studies of Science. San Diego, United States of America.

CAMPOS-CASTILHO, Celeste; HITLIN, Steven.

(2013). Copresence: revisiting a building-block for social interaction theories. Sociological Theory, n. 31, v. 2, p.168-92.

CARSTEN, Janet.

(2004). After Kinship. Cambridge, Cambridge University Press.

CHRISTIAN, Johnna.

(2005). Riding the bus: Barriers to prison visitation and family management strategies. Journal of Contemporary Criminal Justice, v. 21, n. 1, p. 31-48.

COMFORT, Megan.

(2007). Partilhamos tudo o que podemos: a dualização do corpo recluso nos romances através das grades. Análise Social, v. XLII, n. 185, p. 1055-1079.

CUNHA, Manuela.

(2014). Gender asymmetries, parenthood and confinement in two Portuguese prisons. Champ Pénal, v. XI. Disponível em: https:// champpenal.revues.org/8809. Acesso em 22 de janeiro de 2015.

(2002). Entre o bairro e a prisão: tráfico e trajectos. Lisboa, Fim de Século. 
CUNHA, Manuela; GRANJA, Rafaela.

(1994). Malhas que a reclusão tece. Questões de identidade numa prisão feminina. Lisboa, Gabinete de Estudos Judiciário-Sociais.

DIAS, Camila.

(2011). Da pulverização ao monopólio da violência: expansão e consolidação do Primeiro Comando da Capital (PCC) no sistema carcerário paulista. Tese de Doutorado em Sociologia apresentada a Universidade de São Paulo (USP).

DODGE, Mary; POGREBIN, Mark.

(2001). Collateral costs of imprisonment for women: complications of reintegration. The Prison Journal, v. 81, n. 1, p. 42-54.

DUBOIS, Philippe.

(2006). O Ato Fotográfico e Outros Ensaios. Campinas, Papirus.

FARREL, Ann.

(1997). Policies for incarcerated mothers and their families in Australian corrections. Australian and New Zealand Journal of Criminology, v. 31, n. 2: 101-118.

FELTRAN, Gabriel.

(2010). Crime e Castigo na cidade: os repertórios da justiça e a questão do homicídio nas periferias de São Paulo. Caderno CRH, v. 23, p.59-74.

FERREIRA, Pedro Peixoto.

(2005). 0 dentro e o fora. Nada, v. 5, p.18-25. Lisboa, Portugal.

GELL, Alfred.

(1998). Art and agency: an anthropological theory. 0xford, Clarendon.

G0D0I, Rafael.

(2015). Fluxos em cadeia: as prisões em São

Paulo na virada dos tempos. Tese de Doutorado em Sociologia apresentada a Universidade de São Paulo (USP).

GOMES, Silvia; GRANJA, Rafaela.

(2015). Trajetórias de vida e experiências prisionais de mulheres ciganas recluídas. In: GOMES, Silvia; GRANJA, Rafaela (Orgs.); Mulheres e Crime. Perspectivas sobre intervenção, violência e reclusão. Portugal, Edições Humus.

GRANJA, Rafaela.

(2015). Para cá e para lá dos muros: Relações familiares na interface entre o interior e o exterior da prisão. Tese de Doutorado em Sociologia apresentada a Universidade do Minho (Portugal).

GRANJA, Rafaela; CUNHA, Manuela; MACHAD0, Helena.

(2013). Formas alternativas do exercício da parentalidade: paternidade e maternidade em contexto prisional. Ex Aequo, v. 28, p.73-86.

(2014). Mothering from prison and ideologies of intensive parenting: enacting vulnerable resistance. Journal of Family Issues, v. 36, n. 9, p.1212-1232.

GRIMBERG, Samirian.

(2009). Luta de Guerreiros, castigos de ninjas e amor de rainhas: etnografia de uma rebelião prisional. Dissertação de Mestrado em Antropologia Social apresenta a Universidade Federal de São Carlos (UFSCAR).

HAIRSTON, Creasie.

(2007). Focus on children with incarcerated parents. An overview of the research literature. Baltimore, MD, Annie E. Casey Foundation.

HARAWAY, Donna.

(2011). A partilha do sofrimento: relações instrumentais entre animais de laboratório e sua gente. Horizontes Antropológicos, Porto Alegre, v. 17, n. 35, p. 27-64. Disponível em: http://www.scielo.br/scielo.php?pid=S0104$71832011000100002 \&$ script=sci_abstract. Acesso em 15 de junho de 2016.

HAUGEBR00K, Sabrina; FECAROTTA, Steve; STEIN, Yoav.

(2011). Mothers in Prison: The impact of incarceration on motherhood. (28 min.) EUA: Penn Program on Documentaries and the Law (University of Pennsylvania Law School). Disponivel em: http://www.youtube.com/ watch? $v=p q T X t 3 j q c h Q$. Acesso em 8 de agosto de 2013. 
KANE-WILLIS (dir.)

(2008). War on the Family: Mothers in Prison and the Children They Leave Behind. Peace Production, DVD (48 min.).

KARVELI, Vassiliki et al.

(2012). Raising a Child through Prison Bars. Disponivel em: http://www.mothersin-prison.eu/sites/default/files/1/EN_ Manual $\% 20$ for $\backslash \% 20$ Professionals.pdf . Acesso em 10 de agosto de 2013.

LAG0, Natália.

(2014). Mulheres na prisão: entre famílias, batalhas e a vida normal. Dissertação de Mestrado em Antropologia Social apresentada a Universidade de São Paulo (USP).

LATOUR, Bruno.

(2008). Como falar do corpo? A dimensão normativa dos estudos sobre a ciência. In: João Nunes; Ricardo Roque (Org.); Objectos impuros: experiências em estudos sobre a ciência. Porto, Edições Afrontamento.

(1994). Jamais fomos modernos: ensaio de antropologia simétrica. São Paulo, Ed. 34.

(2005). Reassembling the social: an introduction to actor-network theory. 0xford, 0xford University Press.

LEIFSEN, Esben; TYMCZUK, Alexander.

(2012). Care at a Distance: Ukrainian and Ecuadorian Transnational Parenthood from Spain. Journal of Ethnic and Migration Studies, v. 38, n. 2, p. 219-236.

LEMGRUBER, Julita.

(1983). Cemitério dos Vivos: análise sociológica de uma prisão de mulheres. Rio de Janeiro, Achiamé.

\section{LEVERENTZ, Andrea.}

(2006). The love of a good man? Romantic relationships as a source of support or hindrance for female ex-offenders. Journal of Research in Crime and Delinquency, v. 43, n. 4, p.459-488.

LIMA, Jacqueline Ferraz de.

(2013). Mulher Fiel: as famílias das mulheres dos presos relacionados ao Primeiro
Comando da Capital. Dissertação de Mestrado em Antropologia Social apresentada a Universidade Federal de São Carlos (UFSCAR).

LOBO, Andrea.

(2006). Tão Longe, Tão Perto: organização familiar e emigração feminina na Ilha da Boa Vista - Cabo Verde. Tese de Doutorado em Antropologia Social apresentada a Universidade de Brasília.

LOPES, Rosalice.

(2004). Prisioneiras de uma mesma história: o amor materno atrás das grades. Tese de Doutorado em Psicologia Social apresentada a Universidade de São Paulo (USP).

MADIANOU, Mirca; MILLER, Daniel.

(2012). Migration and New Media: Transnational Families and Polymedia. Londres, Routledge.

MALLART, Fabio.

(2014). Cadeias Dominadas. A fundação Casa, suas dinâmicas e as trajetórias de jovens internos. São Paulo, Terceiro Nome.

MATOS, Raquel; BARBOSA, Mariana.

(2015). Mulheres de nacionalidade estrangeira detidas em Portugal. Breve caracterização de trajetos de vida e envolvimento no crime. In: Silvia Gomes; Rafaela Granja (Orgs.); Mulheres e Crime. Perspectivas sobre intervenção, violência e reclusão. Portugal, Edições Humus.

MATOS, Raquel; MACHAD0, Carla.

(2007). Reclusão e laços sociais: discursos no feminino. Análise Social, v. XLII, n. 185, p.1041-1054.

MCKENZIE, Sean; MENJÍVAR, Cecilia.

(2011). The meanings of migration, remittances, and gifts: the views of Honduran women who stay. Global Networks, n. 11, v. 1, p. 63-81.

MOKI, Michele Peixoto.

(2005). Representações sociais do trabalho carcerário feminino. Dissertação de Mestrado em Ciências Sociais apresentada a Universidade Federal de São Carlos (UFSCAR). 
MOL, Annemarie.

(2002). The body multiple: ontology in medical practice. Durham, Duke University Press.

MORASH, Merry; SCHRAM, Pamela.

(2002). The prison experience: special issues of women in prison. Illinois, Waveland Press.

MUNRO, Vanessa.

(2007). From mothering behind bars to parenting beyond barriers? The right to family life and the politics of imprisonment. Amicus Curiae, v. 69, p.6-9.

NEGRETTI, Natália.

(2015). Madá e Lena entrecruzadas, dois dramas em trama: entre percursos numa tragédia social e uma constituição possível. Dissertação de Mestrado em Antropologia Social apresentada a Pontíficia Universidade Católica de São Paulo (PUC-SP).

PADOVANI, Natália.

(2015). Sobre casos e casamentos: afetos e "amores" através de penitenciárias femininas em São Paulo e Barcelona. Tese de Doutorado em Antropologia Social apresentada a Universidade Estadual de Campinas (Unicamp).

PARREÑAS, Rachel.

(2005). Long Distance Intimacy: Gender and Intergenerational Relations in Transnational Families. Global Networks, v. 5, n. 4, p. 317336.

\section{PAZ, Sabrina.}

(2009). A Caravana do Amor: Um estudo sobre reciprocidades, afetos e sexualidade em um estabelecimento prisional que comporta homens e mulheres em seu interior, Rio Grande/RS. Dissertação de Mestrado em Ciências Sociais apresentada a Universidade Federal de Pelotas - RS.
PRAD0, Antonio Carlos.

(2003). Cela forte mulher. São Paulo, Labortexto editorial.

RETTIE, Ruth.

(2009). Mobile phone communication: extending Goffman to mediated interaction. Sociology, n. 43, v. 3, p.421-38.

RIBAS, Natalia; ALMEDA, Eliabet; BODELÓN, Encarna.

(2005). Rastreando lo invisible: mujeres extranjeras em las cárceles. Barcelona, Anthropos.

ROSA, Susel da.

(2008). A escrita de si na situação de tortura e isolamento: as cartas de Manoel Raimundo Soares. História, imagem e narrativas, n. 7. Disponivel em: http://www.historiaimagem. com.br/edica07setembro2008/escritadesi. pdf. Acesso em 20 de novembro de 2011.

SOARES, Barbara; ILGENFRITZ, Iara.

(2002). Prisioneiras: vida e violência atrás das grades. Rio de Janeiro, Garamond / CESeC.

\section{VEREA, Cristina P.}

(2007). Maternidad en prisión. Guadalajara, Universidad de Guadalajara.

\section{Recebido em}

outubro de 2017

\section{Aprovado em}

março de 2018 